\title{
Chemical changes in soil with use of pelletized organomineral fertilizer made from biosolids and sugarcane filter cake
}

\section{João George Moreira ${ }^{1}$, Julio Cesar Delvaux*2, Mara Lúcia Martins Magela ${ }^{1}$, Vanderley José Pereira ${ }^{1}$, Reginaldo de Carmargo ${ }^{1}$, and Regina Maria Quintão Lana ${ }^{1}$}

\author{
${ }^{1}$ Institute of Agrarian Sciences, Federal University of Uberlândia, Uberlândia, Minas Gerais, Brazil \\ ${ }^{2}$ Federal Institute of Education, Science and Technology of Triângulo Mineiro, Ituiutaba Campus, Ituiutaba, Minas \\ Gerais, Brazil
}

\section{Corresponding author: juliodelvaux@iftm.edu.br}

\begin{abstract}
Soil fertility has become an interconnected aspect of modern agriculture, incorporating factors such as nutrient availability from soil, and its revision has become necessary for ensuring sustainability. Therefore, to understand the solubility of nutrients from organomineral fertilizers pelleted with biosolids and sugarcane filter cake, and to evaluate the resulting chemical changes in soil from its use, an experiment was performed in a completely randomized design. The experiment was done with four replicates in a 3 $\times 5+1$ factorial scheme, using three fertilizer sources (mineral fertilizer, organomineral fertilizer pelletized with biosolids, and organomineral fertilizer pelletized with the filter cake); five doses $(60 \%, 80 \%, 100 \%, 120 \%$, and $140 \%$ of the recommended dose of fertilization for corn); and an additional control treatment (absence of fertilization). The formulation of the organomineral fertilizers was 5-17-10 with $10 \%$ total organic carbon. All fertilizer sources were packed in a microfiber cloth positioned $1 \mathrm{~cm}$ below the surface of the soil and incubated for 60 days. Subsequent evaluation of chemical attributes: $\mathrm{pH} \mathrm{H}_{2} \mathrm{O}$ (1:2.5); pH SMP (ShoemakerMcLean-Pratt); and the content of exchangeable aluminum, phosphorus, potassium, calcium, magnesium, silica, and organic matter within the soil was done. Organomineral fertilizers pelleted with biosolids or filter cake do not acidify the soil, but they were found to reduce aluminum saturation and promote a slow release of nutrients, which allowed a more balanced base in the soil. This then ensured a better balance of nutrients, with greater cation exchange capacity, base sums, and base saturation. The use of these fertilizers can contribute to stabilizing the $\mathrm{pH}$ of the soil with fewer applications of acidity correctives.
\end{abstract}

Keywords: Biofertilizer, sewage sludge, agro-industrial waste

\section{Introduction}

The management of soil fertility in agriculture is based on the availability of soil nutrients to crops. Modern soil science postulates a connection between soil fertility and other factors such as system sustainability, soil enrichment from organic matter, the solubility and dynamics of nutrient sources, and the residual effect of fertilizers (Lehmann and Kleber, 2015). The generation of industrial and anthropogenic waste negatively affects springs, landfills, and surrounding regions. Many of these residues do not have an appropriate destination, and agriculture is one of the most significant sectors contributing to this phenomenon (Pires and Mattiazzo 2008; Rossol et al., 2012).

Residues such as sugarcane filter cake have consolidated reuse processes, contributing to an increase in the sustainability of the production chain. This has contributed a proven reduction in the amount of mineral fertilizers that need to be added to crops, and consequent reduction of production costs (Nogueira and Garcia, 2013; Ramos et al., 2015). Furthermore, the recent use of biosolids from sewage sludge has also gained interest as a component of biofertilizers, which could then be used as a promising alternative to commercial fertilizers. In this way, beneficial use as a source of soil nutrients is garnered for the allocation of the growing volume of material generated in sewage treatment plants (Quintana et al., 2011; Mota et al., 2018). There remain difficulties in the reuse of this material, which has a high pollutant potential, in Brazil; however, its use in agriculture is indeed possible with appropriate sterilization and stabilization techniques (Alves Filho et al., 2016).

The recent development of the pelletized organomineral fertilizer industry has absorbed these by-products, adding wealth to environmental liabilities. However, agricultural research still has a long way to go regarding organic fertilizer sources, such as biosolids of varying composition. Provenance demonstrates the need for improved knowledge of their properties such as solubility, the chemical and physical changes that they bring about in the soil, and how they relate to agricultural crops (Oliveira et al., 2017).

The use of pelletized biofertilizers made from sugarcane filter cake and sewage sludge has provided good agronomic 
results in sugarcane crops (Teixeira et al., 2014), Brachiaria (Resende Junior et al., 2016), sorghum (Oliveira et al., 2017), and soy (Mota et al., 2018). However, little is known about the effects of these fertilizers on the chemical properties of the soil. Thus, the objective of this study was to evaluate the solubilization of nutrients, and assess the changes in the chemical properties of the soil due to the contribution of different doses of organomineral fertilizers pelleted from biosolids and sugarcane filter cake.

\section{Results and Discussion}

\section{Effects on soil acidity}

The use of biosolid fertilizer led to increased $\mathrm{pH}$, while the $\mathrm{pH}$ observed when using the filter cake and mineral fertilizers did not differ from that of the control (Table 1). For organomineral sources, higher $\mathrm{pH}$ stability was observed, which was attributed to soil buffering promoted by organic matter. The organic matter presents high quantities of carboxylic and phenolic radicals, which increase the CTC and the buffering power of the soil, thereby reducing the acidity of the solution. This effect can be attributed to the presence of calcium oxides in the filter cake from the addition of the material in the broth clarification process (Prado et al., 2013) and in the biosolid from the need to eliminate pathogens present in the waste (Alves Filho et al., 2016).

There was a difference in the potential acidity of the different fertilizers, with better results observed from using the organomineral sources, especially that containing biosolids (Table 1). A more acidic $\mathrm{pH}$ favored increased aluminum saturation, because the soil was not corrected. Thus, the effect of fertilization is highly relevant and treatment formulated with biosolid presented better results than the control. These results were also superior to those from the filter cake (Table 1).

\section{Effects on nutrient content and aluminum saturation}

Nutrient release by the organomineral fertilizer improved the balance of the soil, allowing gradual reductions in aluminum saturation due to the mineralization of the organic sources. A $1 \%$ reduction in aluminum saturation was observed for each $8.20 \%$ increase in fertilizer dose (Figure 1). The addition of filter cake to soil improves soil quality by increasing macro- and micro-nutrient content, and by reducing aluminum content (Almeida Júnior et al., 2011). Organomineral fertilizers made from filter cake and biosolids allow the controlled release of nutrients, thereby favoring improved soil conditions for the development of plants (Oliveira et al., 2017).

The acidity results indicate a positive effect of the organomineral sources in relation to aluminum saturation, emphasizing the effect of organomineral sources in reducing exchangeable acidity. In general, the studied sources did not change the $\mathrm{pH}$ or the forms of acidity considerably; however, it was noted that the mineral fertilizer promoted greater soil acidification.

After 60 days of soil incubation, uniformity was observed between sources with the exception of the phosphorus content in the mineral source, which remained higher (Table
2). This suggested greater phosphorus solubility in mineral fertilizer and indicated the gradual release of organomineral fertilizers in the initial phase of incubation. Contrary to this, Magela (2017) observed higher levels of phosphorus in the organic sources compared to $100 \%$ of the recommended phosphorus dose in the mineral fertilizer treatment, 30 days after incubation.

Organomineral fertilizers provide phosphorus in a controlled manner, with gradual solubilization throughout the crop. This is owing to the presence of humic substances in the organic matter, which increase the amount of negative charges near the site of phosphate release in these fertilizers (Teixeira et al., 2014). The results indicate the need for trials of longer duration in order to verify the residual effect of phosphorus in organomineral sources.

The application of organic fertilizers was effective at raising soil phosphorus levels. The application of organic residues also restores soil organic acids, which contribute to the reduced adsorption of soil phosphorus (Novais and Smyth, 1999). Thus, the use of organic sources favors the availability of phosphorus in the soil.

When the potassium levels were evaluated, a positive effect of fertilization was observed with all results superior to the control (Table 2). Significant interactions were observed for the higher fertilizer doses (100\%, 120\%, and 140\%), and the results of phosphorus and potassium were most superior in the mineral source. A residual effect of organomineral fertilizers is important for the maintenance of soil fertility over time. Because potassium is monovalent, its retention in soil loads is lower because it is more easily replaced by other elements at the retention sites. Thus, the addition of organic matter allows for the generation of more loads, in order to contain the leaching of this nutrient within the soil (Meurer, 2006). Notably, in sugarcane crops, the addition of filter cake fertilizers may be partially or completely substituted for potassium and phosphate mineral fertilization (Prado et al., 2013; Teixeira et al., 2014).

Calcium and magnesium are important for plant metabolism and ionic soil balance. The organic base sources presented a small portion of calcium from the mineral, ulexite, used in its composition. The results show that the nutrient content remained low in all treatments, which is natural, owing to the low soil content studied and the low supply of fertilizer added to the soil. Thus, it is necessary to evaluate these nutrients in situ to understand how fertilization, with the analyzed sources, interferes in the dynamics of soil ions, their relations, and their availability.

Superior results for the mineral source were observed for calcium (Table 2). However, magnesium content in biosolid treatments was significantly higher than that for other sources at all doses, with significant interaction between source and dose. This indicates the possible presence of magnesium in the composition of the biosolid, favoring the supply of this nutrient to the soil.

Silicon was evaluated to determine the dynamics of this element when fertilizer was applied in the absence of an enriching component. The results revealed that the organomineral source from biosolids presented higher quantities in the soil than the other treatments (Table 2). Furthermore, results similar to those found in the potassium evaluation were observed when the basal sum was 
Table 1. Relationship of factors affecting soil acidity. This table presents the $\mathrm{pH}$ in water, aluminum content, pH-dependent acidity, and potential acidity $\left(\mathrm{mmol}_{\mathrm{c}} \cdot \mathrm{dm}^{-3}\right)$, as well as the aluminum saturation, and aluminum and hydrogen ratios, with total CEC (\%) of soil subjected to different doses of organomineral fertilizer composed of biosolids or filter cake, and mineral fertilizer.

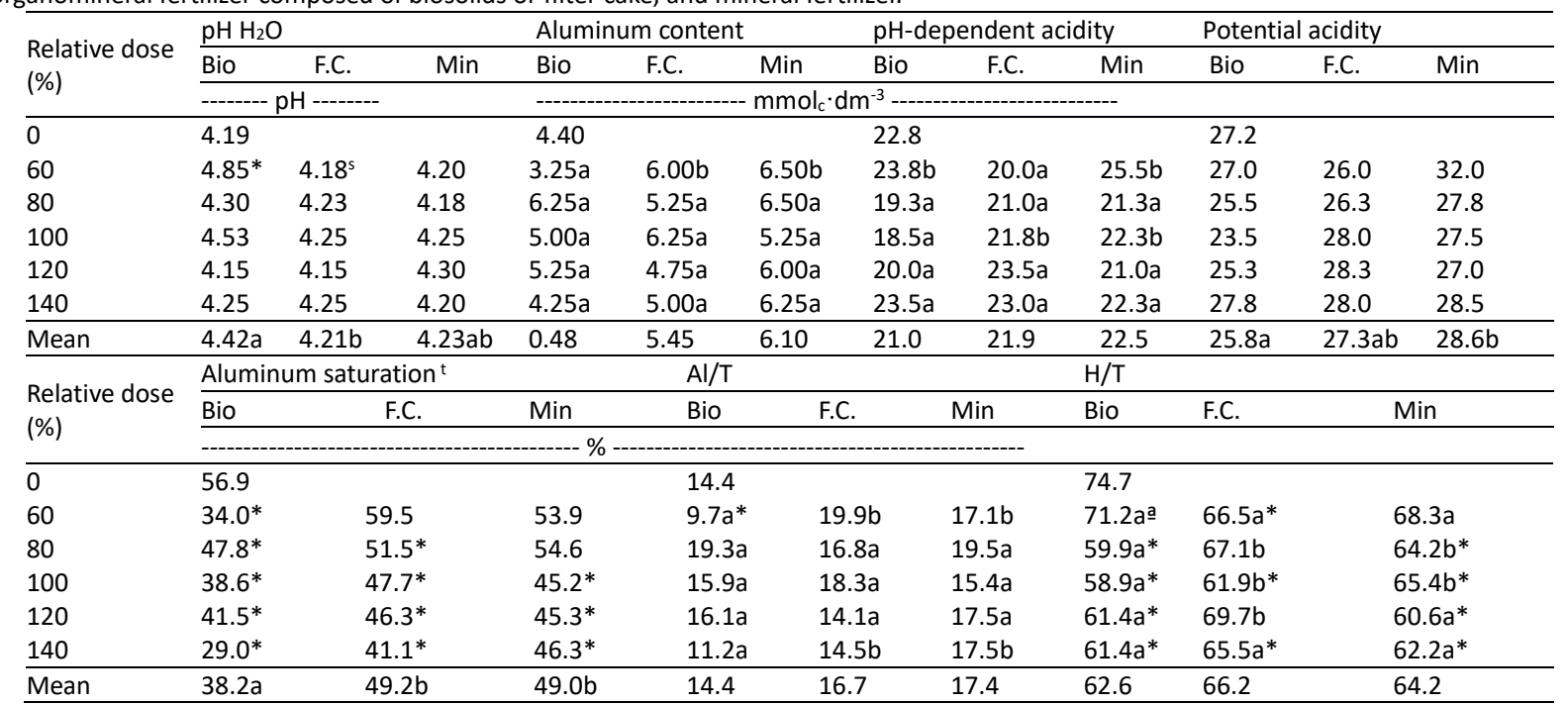

The asterisk $\left({ }^{*}\right)$ indicates values different from the control according to Dunnett's test at 0.05 . Averages followed by distinct letters in the line, differ from each other according to Tukey's test at 0.05 The superscript $\mathrm{t}\left({ }^{t}\right)$ indicates data transformed by the log function $(\mathrm{x}+1)$ to the model assumptions. Bio: organomineral fertilizer pelletized with biosolids; $\mathrm{F} . \mathrm{C} .:$ organomineral fertilizer pelleted with filter cake; Min: mineral fertilizer.

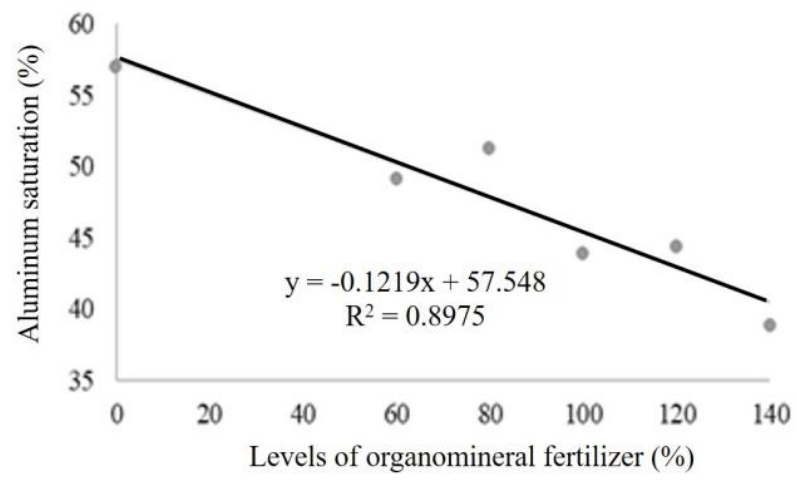

Fig 1. Regression model for aluminum saturation (\%) at different doses.

Table 2. Levels of phosphorus and potassium $\left(\mathrm{mg} \cdot \mathrm{dm}^{-3}\right)$, calcium and magnesium $\left(\mathrm{mmolc} \cdot \mathrm{dm}^{-3}\right)$, silicon $\left(\mathrm{mg} \cdot \mathrm{kg}^{-1}\right)$, sum of bases and total cation exchange $\left(\mathrm{mmol}_{\mathrm{c}} \cdot \mathrm{dm}^{-3}\right)$, basis saturation (\%), and organic matter $\left(\mathrm{g}^{\cdot} \mathrm{kg}^{-1}\right)$ of soil subjected to different doses of organomineral fertilizer composed of biosolids or filter cake, and mineral fertilizer.

\begin{tabular}{|c|c|c|c|c|c|c|c|c|c|c|c|c|c|c|c|}
\hline \multirow{3}{*}{$\begin{array}{l}\text { Relative dose } \\
\text { (\%) }\end{array}$} & \multicolumn{3}{|c|}{ Phosphorus Meh } & \multicolumn{3}{|c|}{ Potassium Meh ${ }^{t}$} & \multicolumn{3}{|l|}{ Calcium } & \multicolumn{3}{|c|}{ Magnesium } & \multicolumn{3}{|l|}{ Silicon } \\
\hline & Bio & F.C. & Min & Bio & F.C. & Min & Bio & F.C. & Min & Bio & F.C. & Min & Bio & F.C. & Min \\
\hline & \multicolumn{6}{|c|}{ - } & \multicolumn{6}{|c|}{---------------- $\mathrm{mmol}_{\mathrm{c}} \cdot \mathrm{dm}^{-3}$------------- } & \multicolumn{3}{|c|}{------ mg·kg-1 ------ } \\
\hline 0 & 0.73 & & & 12.9 & & & 2.06 & & & 0.79 & & & 3.05 & & \\
\hline 60 & 1.18 & 1.05 & 3.23 & $37.0 a^{*}$ & $41.2 a^{*}$ & $38.0 a^{*}$ & 3.56 & 2.20 & 3.57 & $2.08 a^{*}$ & $1.18 \mathrm{ab}$ & $0.89 \mathrm{~b}$ & $4.52 *$ & $4.35^{*}$ & $4.01^{*}$ \\
\hline 80 & 1.98 & 1.53 & 3.48 & $43.5 b^{*}$ & $48.5 a b^{*}$ & $62.0 a^{*}$ & 2.68 & 2.25 & 2.72 & $2.78 a^{*}$ & $1.45 b$ & $0.95 b$ & $4.09 *$ & $4.04 *$ & $4.14^{*}$ \\
\hline 100 & 2.90 & 3.13 & $9.38^{*}$ & $56.5 b^{*}$ & $66.2 b^{*}$ & $90.2 a^{*}$ & 3.46 & 3.06 & 3.39 & $3.51 a^{*}$ & $1.70 \mathrm{~b}$ & $1.09 \mathrm{~b}$ & $4.09 *$ & $4.02 *$ & $3.84 *$ \\
\hline 120 & 3.18 & 4.88 & $6.53^{*}$ & $62.5 b^{*}$ & $67.5 b^{*}$ & $96.2 a^{*}$ & 2.59 & 2.39 & 3.40 & 3.19a* & $1.58 \mathrm{~b}$ & $1.97 b^{*}$ & $3.81^{*}$ & $3.57^{*}$ & $3.51 *$ \\
\hline 140 & $12.0^{*}$ & $7.8^{*}$ & $10.5^{*}$ & $68.2 b^{*}$ & $86.5 a b^{*}$ & $96.7 a^{*}$ & 4.83 & 2.77 & 3.39 & $4.37 a^{*}$ & $1.81 \mathrm{~b}$ & $1.33 \mathrm{~b}$ & $3.58^{*}$ & 3.36 & 3.23 \\
\hline Mean & $4.3 \mathrm{~b}$ & $3.7 \mathrm{~b}$ & $6.62^{\mathrm{a}}$ & 53.5 & 62.0 & 76.6 & $3.42^{\mathrm{a}}$ & $2.5 b$ & $3.3 \mathrm{ab}$ & 3.18 & 1.54 & 1.25 & $4.02 a$ & $3.87 \mathrm{~b}$ & $3.7 b$ \\
\hline \multicolumn{5}{|c|}{ Relative doseSum of bases } & \multicolumn{3}{|c|}{ Cation exchange capacity } & & \multicolumn{3}{|c|}{ Basis saturation $^{\mathrm{t}}$} & \multicolumn{4}{|c|}{ Organic matter } \\
\hline \multirow[t]{2}{*}{ (\%) } & Bio & F.C. & & Min & Bio & F.C. & Min & & iso & F.C. & Min & Bio & F.C. & & Min \\
\hline & \multicolumn{7}{|c|}{ - } & & \multicolumn{3}{|c|}{-----------\%------------ } & \multicolumn{4}{|c|}{ - } \\
\hline 0 & 3.30 & & & & 30.5 & & & & 0.9 & & & 11.3 & & & \\
\hline 60 & $6.45^{*}$ & 4.05 & & .45 & 33.5ab & $30.1 b$ & $37.5 a *$ & & $9.1^{*}$ & 13.5 & 14.6 & 16.7 & 14.8 & & 3.0 \\
\hline 80 & $6.63^{*}$ & 5.00 & & .33 & $32.1 \mathrm{a}$ & $31.3 a$ & $33.1 \mathrm{a}$ & & $0.8^{*}$ & 16.0 & 16.2 & 12.3 & 10.0 & & 12.5 \\
\hline 100 & $7.95^{*}$ & 6.93 & & $.55^{*}$ & $31.5 a$ & $34.9 a$ & $34.1 \mathrm{a}$ & & $5.2^{*}$ & $19.8^{*}$ & 19.1 & 16.0 & 8.3 & & 18.5 \\
\hline 120 & $7.38^{*}$ & 5.45 & & $.75^{*}$ & $32.6 a$ & $33.7 a$ & $34.8 \mathrm{a}$ & & $2.5^{*}$ & 16.2 & $21.9^{*}$ & 26.0 & 29.0 & & 16.3 \\
\hline 140 & $10.50 *$ & 6.98 & & $.25 *$ & $38.3 a *$ & $35.0 \mathrm{a}$ & $35.8 \mathrm{a}$ & & $7.4^{*}$ & $20.0^{*}$ & $20.2^{*}$ & 16.5 & 20.3 & & 3.7 \\
\hline Mean & $7.78^{\mathrm{a}}$ & 5.68 & & $47 \mathrm{~b}$ & 33.6 & 33.0 & 35.0 & & $3.0 a$ & $17.1 \mathrm{~b}$ & $18.4 \mathrm{~b}$ & 17.50 & 16.5 & & 12.8 \\
\hline
\end{tabular}

The asterisk $\left({ }^{*}\right)$ indicates values different from the control according to Dunnett's test at 0.05 . Averages followed by distinct letters in the line, differ from each other according to Tukey's test at 0.05 The superscript $t\left(^{t}\right)$ indicates data transformed by the log function $(x+1)$ to the model assumptions. Bio: organomineral fertilizer pelletized with biosolids, F.C.: organomineral fertilizer pelleted with filter cake, Min: mineral fertilizer. 
Table 3. Chemical properties of the sewage sludge biosolid and the sugarcane filter cake.

\begin{tabular}{|c|c|c|c|c|c|c|}
\hline \multirow[t]{2}{*}{ Sources } & \multirow[t]{2}{*}{$\mathrm{pH}_{\mathrm{H} 2 \mathrm{O}^{\mathrm{a}}}$} & COT $^{\mathrm{a}}$ & $\mathrm{N}^{\mathrm{a}}$ & $\mathrm{P}_{2} \mathrm{O}_{5}{ }^{\mathrm{a}}$ & $\mathrm{K}_{2} \mathrm{O}^{\mathrm{a}}$ & $\mathrm{C} / \mathrm{N}^{\mathrm{a}}$ \\
\hline & & \multicolumn{5}{|c|}{ 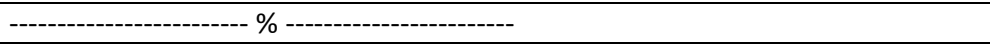 } \\
\hline Sewage sludge & 12.65 & 19.8 & 1.0 & 2.8 & 0.30 & $28 / 1$ \\
\hline Filter cake & 6.81 & 24.0 & 1.0 & 1.1 & 0.27 & $14 / 1$ \\
\hline
\end{tabular}

aEvaluations proposed by Teixeira et al. (2017)

Table 4. Relationship between bases and base relationships with CEC. Total percentage of soil submitted to different doses of organomineral fertilizer composed of biosolids or filter cake, and mineral fertilizer.

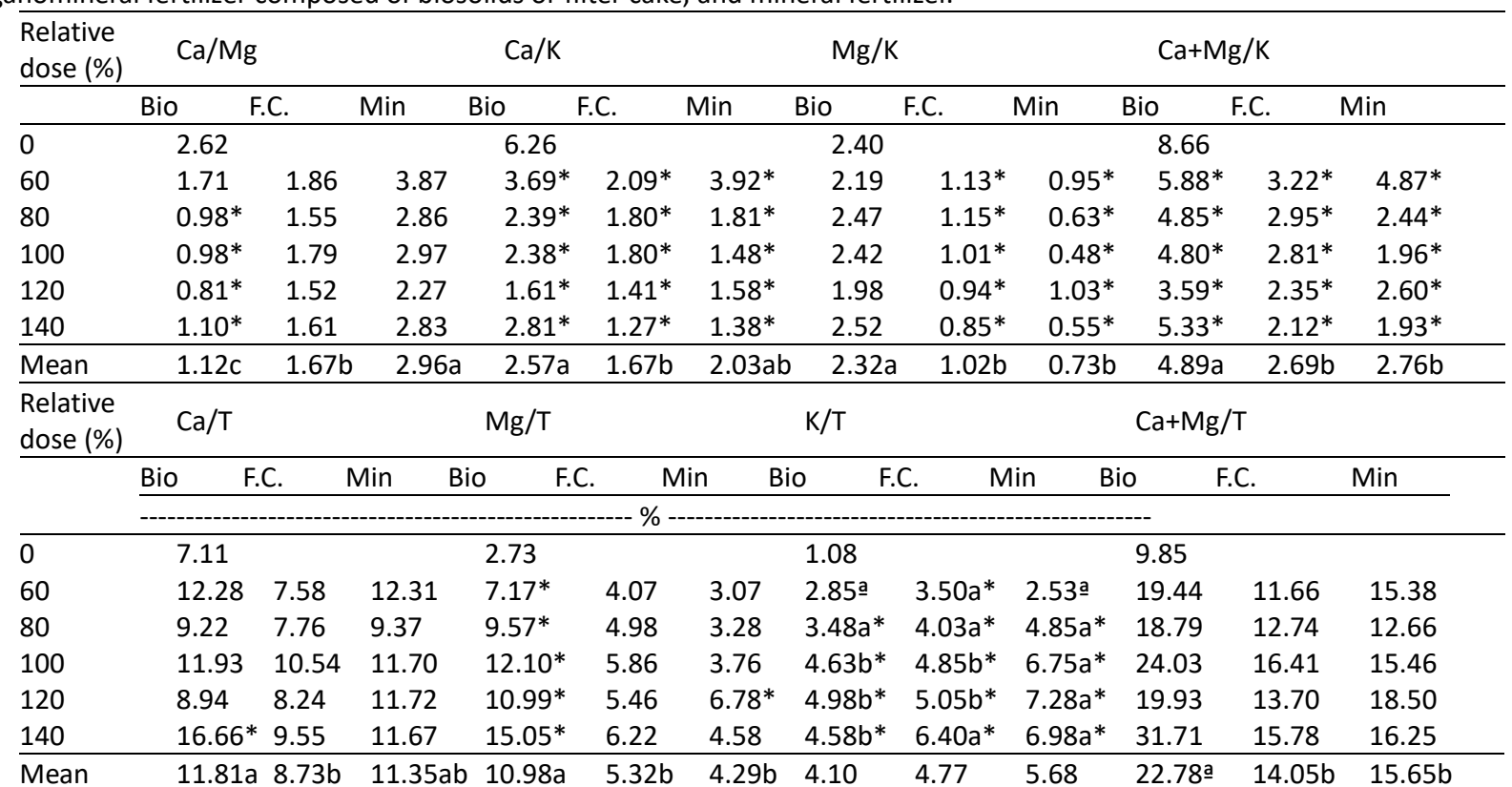

The asterisk $(*)$ indicates values different from the control according to Dunnett's test at 0.05 . Averages followed by distinct letters in the line, differ according to Tukey's test at 0.05 . Bio: organomineral fertilizer pelletized with biosolids, F.C.: organomineral fertilizer pelleted with filter cake, Min: mineral fertilizer, T: CEC at pH 7.

Table 5. Chemical and textural characterization of the red Oxisol

\begin{tabular}{|c|c|c|c|c|c|c|c|c|c|c|c|c|c|}
\hline \multirow[t]{2}{*}{$\mathrm{pH}$} & $\mathrm{P}_{\text {meh }}$ & $\mathrm{K}^{+}$ & $\mathrm{Ca}^{2+}$ & $\mathrm{Mg}^{2+}$ & $\mathrm{Al}^{3+}$ & $\mathrm{H}+\mathrm{Al}$ & BS & $\mathrm{t}$ & $\mathrm{T}$ & $\mathrm{V}$ & $\mathrm{m}$ & OM & OC \\
\hline & \multicolumn{2}{|c|}{$-\mathrm{mg} \cdot \mathrm{dm}^{-3}-$} & \multicolumn{7}{|c|}{---------------- $\mathrm{cmol}_{\mathrm{c}} \cdot \mathrm{dm}^{-3}$------------ } & \multicolumn{2}{|c|}{$--\%$-- } & \multicolumn{2}{|c|}{$\mathrm{dag} \cdot \mathrm{kg}^{-1}$} \\
\hline 4.9 & 0.7 & 0.03 & 0.2 & 0.1 & 0.2 & 2.50 & 0.33 & 0.58 & 2.83 & 12 & 43 & 1.0 & 06 \\
\hline \multicolumn{3}{|c|}{ Coarse sand } & \multicolumn{2}{|c|}{ Fine sand } & & Silt & & & & \multicolumn{2}{|c|}{ Clay } & & \\
\hline \multicolumn{3}{|l|}{431} & \multicolumn{3}{|l|}{387} & 31 & & & & \multicolumn{2}{|l|}{151} & & \\
\hline
\end{tabular}

evaluated (Table 2), and the result was attributed to the high potassium levels provided by the mineral fertilizers.

\section{Effects on cation exchange capacity}

The cation exchange capacity (CEC) is one of the most relevant soil components, representing the soil condition for the movement of cations, such as calcium, magnesium, and potassium. Analysis of the results for each dose, as well as the regression curve of the sources, indicate that the mineral source released the greatest amount of these nutrients. Moreover, there was a significant interaction among factors (Table 2), and only two treatments differed from the control. There was a significant effect of fertilization on soil saturation. However, it is important to note that while the fertilizers surpassed the control, they did not increase the CEC to levels adequate for agricultural crops. Nevertheless, the values were generally higher for the biosolid source
(Table 2).

No differences were observed in organic matter content among treatments (Table 2). It is important to note that while the experiment evaluated the solubility of the fertilizers, the cloth containing the fertilizer did not permit substantial contact between the organic materials of the organomineral sources and the soil. Variations in this variable were not expected.

It is important to emphasize that the quality of the compound used in the formulation of the organomineral fertilizer has a great influence on nitrogen availability in the soil, whereby a very high $\mathrm{C} / \mathrm{N}$ ratio can lead to nitrogen immobilization (Jahnel et al., 1999). For this, it is necessary to promote the complete maturation of the compound, ensuring the necessary degradation and stabilization of its characteristics. In this study, the organic sources had significantly different $\mathrm{C} / \mathrm{N}$ ratios; 28 for the biosolid and 13 for the filter cake (Table 3). 
Differences were also observed in the $\mathrm{Ca} / \mathrm{Mg}$ ratio, with the highest values observed in treatments with mineral fertilizer (Table 4). This result was attributed to the increased magnesium $(\mathrm{Mg})$ content caused by the addition of organic fertilizers. However, fertilization did not cause great changes to the $\mathrm{Ca} / \mathrm{Mg}$ ratio, noting that this relation is usually achieved by the addition of correctives to the soil.

The relationships between bases and $\mathrm{K}$ were weak, as there was no supply of calcium (Ca) and magnesium ( $\mathrm{Mg}$ ) in the treatments (Table 4). Thus, potassium (K) being the denominator caused almost all the treatments to present results that were lower than the control results. However, the $\mathrm{Mg} / \mathrm{K}$ ratio of biosolid pelletized organomineral fertilizer treatments did not differ from the control (Table 4), demonstrating that the nutrient supply was well balanced. The relationships between CEC and nutrients followed a similar pattern, explaining the effective contribution of $\mathrm{K}$ to the soil, whereas the results obtained for most treatments differed from those for the control (Table 4). It should be noted that the $\mathrm{Mg} / \mathrm{K}$ ratio with organomineral biosolids was higher than that of the control and the other sources. The base relations with the CEC confirmed the observed results. Moreover, the $\mathrm{Mg} /(\mathrm{CEC}$ at $\mathrm{pH} 7[\mathrm{~T}])$ ratio was higher than that of the control in all doses of biosolid pelleted organomineral fertilizer (Table 4). Generally, fertilization with organomineral fertilizers promotes a good balance between soil nutrients and CEC, which is desirable with the application of this type of fertilizer.

\section{Materials and Methods}

\section{Formulation of the organomineral fertilizers and the experimental design}

The experiment was conducted between $19 / 09$ and 19/11 of 2016, in a greenhouse located at the Umuarama Campus of the Federal University of Uberlândia $\left(18^{\circ} 91^{\prime} 86^{\prime \prime} \mathrm{S}\right.$, $48^{\circ} 27^{\prime} 72^{\prime \prime} \mathrm{W}$; $800 \mathrm{~m}$ above sea level). The experiment was conducted in a completely randomized design, with four replicates in the factorial scheme, $3 \times 5+1$. Three fertilizers were tested: organomineral fertilizers pelleted with biosolid or sugarcane filter cake (Table 3) (hereby referred to as biosolid or filter cake), and mineral fertilizer. Five doses of the three fertilizer sources (namely 60\%, $80 \%, 100 \%, 120 \%$, and $140 \%$ of the recommended dose of fertilizer for corn crops) were used, as well as a control, which undertook no fertilization. For the mineral fertilizer, urea, triple superphosphate, and potassium chloride were used as sources of nitrogen, phosphorus, and potassium, respectively. Fertilizer doses were defined based on the recommended $\mathrm{P}_{2} \mathrm{O}_{5}$ content to be applied to soil (Soil Fertility Commission of the State of Minas Gerais [CFSEMG], 1999).

The organomineral fertilizers were formulated at concentrations of $5-17-10$ (10\% of total organic carbon [TOC]). The sewage sludge used in the composition of the organomineral fertilizer came from the sewage treatment plant of the Municipal Department of Water and Sewage (DMAE), located in the city of Uberlândia-MG. The material was sanitized with hydrated lime to eliminate pathogens, reduce moisture, and for biological stabilization (Alves Filho et al., 2016). Additionally, the filter cake was obtained from the Vale do Tijuco Sugar Mill (Table 3). Pelletized organomineral fertilizer was produced by the balanced addition of mineral components to the organic base until the NPK ratio was 5-17-10. Processing resulted in pellets $5 \mathrm{~mm}$ long and $0.8 \mathrm{~mm}$ in diameter, with hardness equal to 5 $\mathrm{kgf} \cdot \mathrm{cm}^{-3}$ and $10 \%$ moisture.

The incubation test using red sandy loam of loose texture (Table 5) was conducted using the method, "Solubility of Fertilizers Containing Silicon - Incubation Method," version 15.2010, with modifications (Korndörfer, 2004). Each experimental plot consisted of a plastic container containing $1 \mathrm{~kg}$ of fine dirt that was air dried (FDAD), plus fertilizer at the respective dose.

The fertilizers were packed in microfiber cloths positioned in $1 \mathrm{~cm}$ depths within the soil. This differed from the original method, where the fertilizer was incorporated into the soil by agitating them both in a plastic bag. The set was maintained with moisture close to $80 \%$ of the vessel's retention capacity, and the amount of water added was determined by the difference in weight. The pots were incubated for 60 days and samples were always taken from below the fertilizer-filled cloths. After collection, the samples were dried, sieved, and analyzed to determine their chemical attributes.

\section{Evaluation of soil chemical characteristics}

The values of $\mathrm{H}_{2} \mathrm{O}(1: 2.5), \mathrm{pH}, \mathrm{SMP}$, and the content of exchangeable aluminum, phosphorus, potassium, calcium, magnesium, silica, and organic matter in the soil were evaluated (Teixeira et al., 2017) using methodology proposed by Korndörfer (2004).

\section{Statistical analyses}

Data were tested for normality of residues (KolmogorovSmirnov) and homogeneity of variances (Levene). The data were also submitted to an $\mathrm{F}$ test. All data were assessed at a significance level of 0.01 . Fertilizer sources were analyzed using Tukey's test, and fertilizer doses were analyzed by regression to obtain the ideal statistical model. When the regression models did not adjust $\left(R^{2} \geq 70 \%\right)$ they were omitted, and inferences were made on the differences between the doses and the additional treatment (absence of fertilization) by Dunnett's test at a significance level of 0.05 .

\section{Conclusions}

Pelletized organomineral fertilizers made from biosolids and filter cake from sugarcane do not lead to acidification of the soil, thereby reducing the quantity of soil correctives that would usually be required. The contribution of these products stabilizes soil $\mathrm{pH}$, reduces aluminum saturation, and promotes a better balance between soil bases.

\section{References}

Almeida Júnior $A B$, Nascimento $C W$, Sobral MF, Silva FB, Gomes WA (2011) Soil fertility and uptake of nutrients by sugarcane fertilized with filter cake. Revista Brasileira de Engenharia Agrícola e Ambiental, 15, 1004-1014. 
Alves Filho A, Camargo R, Lana RMQ, Moraes MARB, Maldonado AICD, Atarasi RT (2016) Treatment of sewage sludge with the use of solarization and sanitizing productsfor agricultural purposes. African Journal of Agricultural Research, 11, 184-191.

Comissão de Fertilidade do Solo do Estado de Minas Gerais [CFSEMG]. (1999) Recomendações para o uso de corretivos e fertilizantes em Minas Gerais: 5ạ aproximação.

Korndörfer GH (2004) Análise de silício: solo, planta e fertilizante. Instituto de Ciências Agrárias, Universidade Federal de Uberlândia.

Jahnel MC, Melloni R, Cardoso EJBN (1999) Urban solid waste maturity. Scientia Agricola, 56, 301-304.

Lehmann J, Kleber M (2015) The contentious nature of soil organic matter. Nature, 528, 60.

Magela MLM (2017) Sources of organic matter in the composition of pelletized organomineral fertilizers in maize (Master). Federal University of Uberlândia, Uberlândia, MG, Brazil.

Meurer EJ (2006) Potassium. In Fernandes M, Mineral nutrition of plants (pp. 282-295). Viçosa, MG, Brazil: Brazilian Society of Soil Science.

Mota RP, Camargo R, Lemes EM, Lana RMQ, Almeida RF, Moraes ER (2018) Biosolid and sugarcane filter cake in the composition of organomineral fertilizer on soybean responses. International Journal of Recycling of Organic Waste in Agriculture, 1-7.

Nogueira MAFS, Garcia MS (2013) Gestão dos resíduos do setor industrial sucroenergético: estudo de caso de uma usina no município de Rio Brilhante, Mato Grosso do Sul. Revista Eletrônica em Gestão, Educação e Tecnologia Ambiental, 17, 3275-3283.

Novais RF, Smyth TJ (1999) Fósforo em solo e planta em condições tropicais (No. 631.422 N934). Universidade Federal de Vicosa, Vicosa, MG (Brasil). Departamento de Solos.
Oliveira DP, de Camargo R, Lemes EM, Lana RMQ, Matos ALIA, Magela MLM (2017) Organic matter sources in the composition of pelletized organomineral fertilizers used in sorghum crops. African Journal of Agricultural Research, $12,2574-2581$.

Pires AMM, Mattiazzo ME (2008) Avaliação da viabilidade do uso de resíduos na agricultura. Embrapa Meio Ambiente. Circular Técnica.

Prado RDM, Caione G, Campos CNS (2013) Filter cake and vinasse as fertilizers contributing to conservation agriculture. Applied and Environmental Soil Science, 2013.

Quintana NRG, Carmo MS, Melo WJ (2011) Sewage sludge as fertilizer: agricultural productivity and economic rentability. Nucleus, 8.

Ramos LA, Lana RMQ, Korndorfer GH, Silva AS (2015) Effect of organo-mineral fertilizer and poultry litter waste on sugarcane yield and some plant and soil chemical properties. African Journal of Agricultural Research, 12, 20-27.

Resende Junior JC, Camargo R, Lana RMQ, Alves Filho A, Matos ALA (2016) The effects of sewage sludge, mineral and organic fertilizers on initial growth of Urochloa brizantha cv Marandu (Hochst. ex A. Rich.) RD Webster. African Journal of Agricultural Research, 11, 3460-3470.

Rossol CD, Scalon Filho H, Berté LN, Jandrey PE, Schwantes D, Gonçalves Jr AC (2012) Characterization, classification and disposal of waste in agriculture. Scientia Agraria Paranaensis, 11, 33-43.

Sheldrick BH, Wang C (1993) Particle size distribution. p. 499-512. MR Carter (ed.) Soil sampling and methods of analysis. Lewis Publ., Boca Raton, FL. Particle size distribution. p. 499-511. In MR Carter (ed.) Soil sampling and methods of analysis. Lewis Publ., Boca Raton, FL.

Teixeira WG, Sousa RTX, Korndörfer GH (2014) Response of sugarcane to doses of phosphorus provided by organomineral fertilizer. Bioscience Journal, 30.

Teixeira PC, Donagemma GK, Fontana A, Teixeira WG (2017) Manual de Métodos de Análise de Solo. Embrapa SolosLivro técnico (INFOTECA-E). 